\title{
XVIII.
}

\section{Ueber einen Fall von partiellem Mangel des Obrläppohens.}

\author{
Von \\ Prof. G. Gradenigo \\ in Turin. \\ (Mit 1 Abbildung.)
}

Wie ich in einer meiner früheren Arbeiten erwähnte, sind mehr oder weniger bedeutende Missbildungen des Obrläppchens nicht selten, und zwar angefangen von jener Form, die als adhärirendes Ohrläppchen bekannt ist, und jenen Fällen, in welchen dasselbe nach Binder fehlt, vom adhärirenden und auf die Backen fortgesetzten Ohrläppchen bis zur congenitalen Fissur desselben, die zu einer gelehrten Discussion unter den Anthropologen Veranlassung gab. Der Fall jedoch, den ich im Folgenden beschreiben will, unterscheidet sich von den gewöhnlichen Fällen, und da ich nie etwas Aehnliches sah und auch in der Literatur keine Erwähnung desselben finde, so halte ich es für zweekmässig, denselben hier durch eine Figur und eine kurze Beschreibung zu illustriren.

Es handelte sich um einen kräftigen, 11 Jahre alten Knaben, der sonst ganz normal gebaut war. Anch die linke Ohr* muschel ist in ihrem oberen Theile gut geformt; wie man aber aus der beigegebenen Figur ersieht, fehlt der vordere untere Theil des Läppchens, dessen hin-

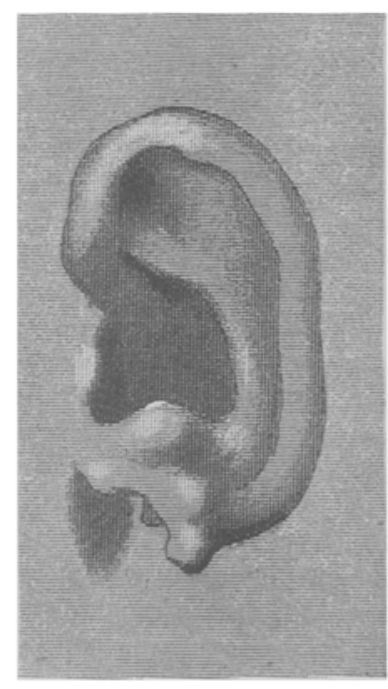
tere Portion nach unten frei berabhängt. Die Distanz zwischen der Spitze der Ohrmuschel und dem tieferen Theile des Ohrläppchens ist deshalb links ungefähr um $1 \mathrm{Cm}$. verktirzt im Vergleiche mit der 
314 XVIII. GRADENIGO, Fall von partiellem Mangel des Obrläppchens.

rechten Seite, wo die Ohrmuschel vollständig normal ist. Die Ränder des Substanzverlustes zeigen keine Narben und sind $3 \mathrm{Mm}$. dick. Ungefähr in der Mitte derselben erstreckt sich nach unten auf der hinteren Fläche der Ohrmuschel eine $3 \mathrm{Mm}$. hohe, nicht knorplige Hervorragung, welche von den Angehörigen des Kindes für den ektopischen Theil des fehlenden Läppchens gehalten wird.

Die sehr intelligente Mutter des Kindes behauptet, dass diese Anomalie congenital sei, und dass das Kind, welches sie immer bei sich hielt, nie an einer localen Krankheit litt. 